\title{
The Political Ethics of Khalil Bishri in Al-Durr Al- Rambani
}

\author{
Sarjuni \\ Tarbiyah Department, Islamic Faculty \\ Sultan Agung Islamic University \\ Semarang, Indonesia \\ alfahanin@gmail.com
}

\author{
Agus Irfan \\ Islamic Civilization Department, Islamic Faculty \\ Sultan Agung Islamic University \\ Semarang, Indonesia \\ agus.irfan@unissula.ac.id
}

\begin{abstract}
This article discusses the idea of Political Ethics from one of the Indonesian scholars named Khalī Bishrī in the Book of Al-Durr Al-Rambāni. This study is under descriptive qualitative research using a socio-historical approach and sociology of knowledge that studies the interrelationships between thought and society. The results of this paper state that in Islam; the political problem is the area of ijtihādī which has strong roots in Islam. The relationship between them can be called a mutually reinforcing symbiotic relationship ('alāqah indimājiyah). One of the influences of Islam in political traditions, for instance is its teachings on ethics that must inspire all policy issues. Even ethical configuration must also inspire the most important elements in the democratic political systems as called political parties. The term animates, explains that Islam as a system does not have to be realized in the form of formalization of sharīa or political Islam movements. In addition to ethics, the goals that result from political dynamics must be in the form of benefit (maqsad al-siyāsah). Therefore, political work carried out in the corridor of truth can be considered as worship and deliver the politician to the noblest profession in the sight of God.
\end{abstract}

Keywords-Khalīl Bishrī, Political Ethics, Political Benefit, Political Party Reform

\section{INTRODUCTION}

The study of political thought, especially those related to ethics in political discipline, is an old theme. Its presence along with the emergence of political science itself. Or even together with the birth of man himself as a political creature (zoon politician) that is impossible to prevent politics. In the context of this study, the issues to be discussed are about political ethics, an idea born from one of the Indonesian scholars and politicians from Rembang, Central Java, Muhammad Khalil Bishri (1942 AD - 2004 AD). The choice was based on the fact that Muhammad Khilil Bishri (hereafter Khalil Bishri) was a phenomenal figure known to the public, especially Javanese and attached to him a figure of an ulama, politician and a sociologist. Although the name Khalil Bishrī may be outrageous with his younger sibling Ahmad Musțafā Bishrī or Gus Mus, but some Indonesians, especially among the santris, will no doubt on his expertise in giving national ideas. The climax of Khalil Bishri became one of the decelerators of the establishment of the National Awakening Party (PKB) along with several other scholars and leaders of the Nahdlatul Ulama.
The idea of Khalil Bishri about political ethics found its relevance when the political dynamics in Indonesia lately showed a shift in political meaning to be reductive. Political or daily dynamism in political activities as a whole is experiencing (borrowing Ermada Riyanto's term) as "redefaction" and not "scientific certification", starting from conversation, debate to issues that are rolled out and disputed. Reducification is a manifestation of the silting process and becomes the antithesis of scientification as a process of activity that prioritizes rationality, scholarship and depth.

In the present context, reducible politics can be seen from the phenomenon of Indonesia which is facing various national exams which are reflected in the fading of nationalism and state defense, the rise of hoax news and the use of SARA sentiments in social political life, the proliferation of radicalism and sectarianism, and widespread corruption and terrorism (as in social and political sciences that have never had a single definition and approach, so too in an effort to define what is meant by terrorism, although the definition of terrorism is very broad but everything departs from the same point, namely the use of violence such as piracy, suicide bombings and so on. In its case, terrorism is traditionally distinguished from other forms of crime, because terrorism is synonymous with political content. As revealed by Viotti and Kauppi that "Terrorism, as politically motivated violence, aims at providing a demoralizing effect on publics and governments") which coincides with the symptoms of poverty, unemployment and economic inequality. All of these national exams helped strengthen the adage that the political world was indeed close to naivety, which helped to diminish the optimism in the life of the nation.

The issue of other national politics that has occurred lately is the rampant phenomenon of religious radicalism which has led to the terrorism movement. This movement carried out in the name of jihad was not only a prima donna for "lay" and scriptural groups in understanding texts, but this anti-stream movement also succeeded in combing "elite" groups with the rampant world of famous campuses becoming the seeds of terrorism. There is a terrible combination that makes college campuses a hotbed of radicalism based on religious dogma, namely the failure of the education system and the massive technology in disseminating information. (The MataAir \& Alvara Research Center research in 2017 involving 1,800 students in 25 leading universities and 2,400 high school high school students said that $23.5 \%$ of students and $16.3 \%$ of high school students agreed with jihad for the establishment of an 
Islamic state or caliphate. $18.6 \%$ of students and $16.8 \%$ of students chose Islamic ideology more appropriate for Indonesia. $17.8 \%$ of students and $18.3 \%$ of students chose the Khilafah compared to the NKRI. $29.5 \%$ of students and $29.7 \%$ of students stated that they would not support non-Muslim leaders. While other studies MataAir \& Alvara Research Center in 2017 involving 1,200 PNS Professionals, BUMN, Private Sector showed that $29.7 \%$ did not support democratically elected non-Muslim leaders and $27.6 \%$ supported sharia regulations because they were considered appropriate to accommodate followers of the majority religion.)

Because placing Islam is more than just religion and ideology, the style of this group is always black and white in seeing the problem. As a result there will always be a debate about Islam as a worldview regarding issues that develop and are directly related to social reality, especially the issue of political ideology which sometimes requires the involvement of a Muslim to support it. In the context of nationality, this radical group also openly stated its rejection of the embedding of Pancasila as the basis and ideology of the Indonesian state. They also believe that democracy is nothing more than a pagan system and regards its device as the tạghūt group.

\section{The ANTHRopological CONSTRUCTION OF POLITICAL THOUGHT KHALIL BISHRI}

Khalil Bishrī was the eldest child born in October 1941 to the couple Kiai Bishrī Musțafā (hereafter Kiai Bishrī) and Ma'rufah binti Kiai Cholil Kasingan. In addition to studying at the People's School (1954), Khalil Bishrī also attended Madrasah Ibtidāiyah (1954), then continued at Taman Siswa Middle School (1956) together with the school at Islamic College (1956). He then continued his education to the Lirboyo, Kediri, East Java Islamic Boarding Schools (1957), Al-Munawwir Krapyak Islamic Boarding School, Yogyakarta (1960), Aliyah Darul Ulum Mekah (1962), and IAIN Sunan Kalijaga Yogyakarta.

Khalil Bishrī also became an important figure in initiating and developing the birth of the Party of Kebangkitan Bangsa (PKB) as a forum for NU's political aspirations. Starting on June 6, 1998, he invited 20 clerics to discuss the matter, and no less than 200 kiai came. It was from this meeting at his house that the idea crystallized until the process of establishing the PKB by the PBNU Working Team. When the PKB was declared on June 23, 1998, Khalil Bishri was still one of the important figures. He became Deputy Chairperson of the PKB DPP Syuro Council, with the Chair of the Syuro Council KH Ma'ruf Amien and Chairperson of the Tanfdiziyah Council Matori Abdul Djalil. His involvement in PKB led him to become a member of the Houe of Representatives from PKB, even to become Deputy Chairperson of the People's Consultative Assembly.

Not only being a politician, in Khalil Bishri there is also a figure of a kiai, writer, and at the same time a Sufi. He held the responsibility of being a caregiver in the Raudhatut Thalibin Islamic boarding school and still teaching bandongan such as Alfiyah, Sharah Fath al-Mu'īn, Jam'u al-Jawāmi', and Iṇyā 'Ulūmidd̄̄n. Presumably, the personality of Khalil Bishri continued his extended family breed as great kiai and great writers, including his view of political ethics which was no different from the political views of his father, Kiai Bishri Muștiafā.
In political matters, Kiai Bishrī holds that Islamic law can be implemented in Indonesia, but without having to use religious formalism in the form of an Islamic state (Dār alIslām). Kiai Bishrī supports the concept of Pancasila as an insight into the archipelago, as well as the pillars of the NKRI. He encourages communication between Ulama and Zu'ama, which aims to produce reliable cadres in Nahdlatul Ulama. In this context, Kiai Bishri was of the view that the struggle could be carried out in two ways: namely the political path and the path of preaching / education.

In the political field, Kiai Bishrī was once a constituent member. His struggle can be traced when he is involved in parliament and outside the state structure. Kiai Bishri is also known as a figure who supports Sukarno's ideas, namely the concept of Nasakom (Nationalist, Socialist, and Communist). Kiai Bishrī notes, that when parties have different ideologies, they must compete healthily in the Indonesian corridor, while maintaining the NKRI. However, Kiai Bishri was also the sharpest critic when Nasakom became a political tempest. Kiai Bishri's political diplomacy is not only in the local sphere, but also influences national political policies.

Political diplomacy Kiai Bishri is worthy of example. He did not separate politics and religion, so in dealing with his political opponents, he still used ethics and fiqh as a reference for attitude. Therefore, there was never a conflict between Kiai Bishrī and his political opponents. NU activists in his day were very respectful of Kiai Bishrī, such as KH. Idham Cholid, KH. Akhmad Syaichu, Subhan ZE and several other scholars.

Despite being a politician, the ulema of Khalil Bishrī did not fade. He continued to teach Koran and became a caretaker for the Raudhatut Thalibin Islamic Boarding School until he died at the age of 62 on August 23, 2004. He left a wife named $\mathrm{Hj}$. Muhsinah, eight children, and a number of grandchildren. Aside from being a politician, Khalil Bishrī is also a writer, his books which have been published are "Kami Bukan Kuda Tunggang" and "Ketika Biru Langit". While other works in the prominent political field are Al-Durr Al-Rambani, a book of Fiqh Siyāsah or a book that discusses politics in Islam that contains issues of ideology and state political systems and includes many questions about political ethics.

\section{OVERVIEW OF THE BOOK OF AL-DURR AL-RAMBĀNĪ}

Kitab Al-Durr Al-Rambān̄̄ by Khalil Bishrī, written in Arabic, as a communication language commonly used in the culture of boarding schools, both active and passive. The book printed and published by the Honorary Council of the Republic of Indonesia is a reference to adding political references in Islam, especially when faced with the duties and obligations of scholars as moral agents. The added value of this book lies in Khalil Bishri's not only emphasizes Islamic political issues on classical issues, but contextualize the nationality and Indonesian's locus. As Khalil Bishri himself wrote that Indonesian independence was proclaimed by Soekarno and Muhammad Hatta was not a free gift or independence gained with blood drops and all the efforts of this nation had made.

Therefore, after this independence, the Indonesian people have the same rights and obligations to breathe the air of freedom in this democratic country. As a sovereign country, Indonesia has laws that regulate the life of the nation and freedom of association known as the 1945 Constitution with 
its opening formula, namely Pancasila. Basic for the state, both the Pancasila and the Basic Law serve as references in formulating serious regulations and policies. In an elegant manner, the context of nationality is the essence of politics that connects leadership and popularism.

The description above is that Khalīl Bishrī wishes to convey in the book Al-Durr Al-Rambana. Therefore, in outlining his ideas, Khalil Bishri wrote at least 12 coherent articles in one chapter with other articles, including: 1. Introduction, 2. Political Nature, 3. Political Relations and Sharī'ah, 4. Between Politics and Jihad, 5. Politics and Democracy, 6. Mushawarah, 7. Political Parties, 8. Community Law, 9. Political Ethics, and 10. Restrictions on Political Position, 11. Representative Rights and Systems, 12. Closing.

As the book Fiqh al-siyāsah which breaks down political issues in the Islamic landscape, the discussion in these articles is more nuanced in Sunni fiqh. One example is the necessity of the people to obey and submit to the government, which is as Al-Ahkām al-Sultāniyah by Al-Mawardī and Al-Iqtishād fi aI'tiqād and several other Al-Ghazālī works.

\section{THE IDEA OF POLITICAL ETHICS KIAI KHALIL BISHRI}

\section{A. Politics of Maslahat}

Politics is the art of managing the interests of citizens. Civilized politics is the noblest form of a noble civilized nation. Quoting al-Muqrīzì's opinion, Gus Khalīl writes that politics is a law of art to safeguard civilization, benefit and order. Likewise, the understanding written by Abu al Wafā ibn 'Aqīl that politics is a policy and activity that leads to civilization and keeps it away from political banality, even though it is not stated in revelation.

The benefit of this type of politics is the most important spectrum in politics driven by love and humanity. Without both, politics is held only for political interests or merely procedural democracy which bases itself on mere political rights which are neglecting the values and morality of the nation. The uprightness of justice accompanied by an attitude of tolerance in the nation is the essence and substance of political goals (Maqāșid al-Sharī'ah) in fact. In this case Khalil Bishri mentioned that:

"The political goal is clear, namely to uphold truth and justice among humans and liberate them from degradation and tyranny by upholding tolerant Sharia as the main goal by taking the maslahat to eliminate the maḍārāt. (Another goal is to build a culture of love and affection among fellow countrymen and humans in general which is based on Allah's word so that unity and strength will be formed which can deliver their authority both religion and nation. "

Note Muhammad Khalil Bishrī above, is a basis of the opinions of the majority of scholars who emphasize the most important elements in politics such as benefit, justice, shūrā, equality, freedom, and welfare of society, although not explicit in standard texts. With the above understanding, it can be seen how Islam is very tolerant and moderate in looking at political issues by emphasizing its Maqāșid al-Siyāsah aspects. According to Muhammad al Salābi, the attitude of moderation (al-wasatiyah) especially in political matters has several characters such as positive and superior charity (al khairiyyah), full of justice (al-'adl), enthusiasm to simplify and become a problem solver (al-yusr wa raf'ul haraj), full of wisdom, between (al bainayah), and consistent (al-istiqāmah).

Ali Muhammad al Șalābī further explained that the meaning of "al-khairiyyah" can be interpreted as the best and superior people characterized by QS. Al-Imran: 110, as a people who are consistent in calling for good and forbidding munkar, all of which are accompanied by feelings of faith in Allah. Another characteristic of al wasatiyyah is the nature of the intermediate (al bainayah) as a choice of a balanced, moderate and fair attitude. Not trapped in the right extreme (al ghuluw) and left extreme (al ifrāt), both of which do not reflect Islamic character and values.

Such political art in the term Khalil Bishri is called alSiyāsah al-'Ādilah which is in harmony with the maqāqid alsharī'ah by making religion a source of ethics. Politics using reference to religious ethics is something that is justified, even obliged and not vice versa using religious clothes for political purposes. In the context of the necessity of power accompanied by ethics, politics is not only the art of managing but it is a noble act because it is based on ethical and moral values.

In other terms, if a particular religious group pursues political power in order to pave the way for discriminatory actions, religion here is like an evil force that seizes power by exploiting the mechanism of democracy. However, if religious groups throw themselves into politics because they want to uphold justice and equality, religion can be a blessing for the modern democratic system.

In his political philosophy, Ibn Khaldūn explained that religion is a force inherent in the source of political power. Religion is the basis of state development, because it can unite elements within the country and make the country stronger to be defeated. Religion also guarantees collective morality, service, kindness and not a source of riots, individual ambitions, and civil denial. Such religious values in the term are now commonly referred to as "political culture".

In contrast to the politics of benefit, it is banal politics as opposed to civilized politics which in the term khalīl bishrī is called al-siyāsah al-limālimah. This banal politics is a type of politics that does not contain the maqāșid al-sharī'ah at all if it is not called destructive politics. It is this political banality that also contributes to the impression of politics as a dirty thing, because in the process it is carried out through indecent methods and far from being ethical or moral. Starting from black campaigns (black campaigns), spreading hoaxes, slander, money politics and so on. Some of these indications further justify the thesis that politics is the same as "who can what, when and how" (who gets what, when and how) as Lasswell said.

The indecent process above also strengthens the Machiavelli's political culture which limits itself to questions about the techniques of seizure and defense of power by a king. This was done with cynicism and extreme. For Machiavelli, politics and morals are two fields which have nothing to do with. According to him, in political affairs, attention to moral norms is out of place because what counts is success.

Machiavelli only knows one rule of political ethics, namely that the good is anything that strengthens the power of the king. Everything that serves that purpose must be justified. 
For him, there is no benefit if we question the moral legitimacy of power because what is decisive is the technique to seize and defend it. It is enough, if the king shows himself to be an assertive, brutal, and that is emphasized by Machiavelli, that he does what is expected by society and the rest there is no problem for Machiavelli.

\section{B. Egalitarian politics}

The consequence of the benefit of the above politics is the realization of the goal of the maqāsid al-sharia, one of which is the birth of an egalitarian policy and political system. Sharia, as a moral source has taught how a believer positions himself as a servant and at the same time can give peace (the word safe from faith) to other people or people. In macro terms, all religions always teach good values to their people. It gave birth to mutual respect and tolerance towards fellow human beings who have a commitment to maintain the integrity of the nation. In the context of nationality, how does one group not feel superior to other groups that have the potential to divide the unity.

This message has an important relevance in the midst of the current condition of the Indonesian people who are faced with the phenomenon of political models that are quite far from the ideal political substance of citizens. Political models that prioritize group sentiment by blasphemy, punishing and persecuting different and opposite political groups. Even by hijacking religious verses though. The choice of words and sentences for other groups with various kinds of inappropriate designations such as kampret, cebong, satan and dajal is a form of uncivilized politics that has been rife lately.

Egalitarian as the principle of democratic life also negates the politics of violence which the authorities usually do as part of hegemony. Politics of violence can also be carried out by some people in a political activity as a result of different perspectives and interests. This type of politics, both carried out by the regime against its people in order to create compliance or be carried out by the community towards its leaders, cannot be justified. In addition to contradicting the principles of democracy that guarantee freedom of political expression from the shadow of threats, the politics of violence inherent in the political structure will also harm the achievements and outcomes of the democratic process. Even the damage takes a long time to be forgotten, especially repaired. History records that this nation had dark trails that dissolved in political violence starting from the 1965, 1984 tragedy (the Tanjung Priok incident), 1998 (May riots) and so on.

Indonesia, as a country that adheres to the Pancasila democracy as a whole, becomes a joint commitment to want the birth of brotherhood and this is the key to achieving peace. The five articles contained in the Pancasila dictum reflect Islamic values that uphold freedom, equality and the tradition of deliberation.

Egalitarian messages in politics are based on QS. An-Nisā: 135 and QS. Al-Māidah: 8, which explains the obligation to uphold the truth by being egalitarian. Khalil Bishrī distinguishes the term al-qist from al-'adl even though these two words are commonly interpreted equally. Al-qist is a balanced picture between giving and demanding, between expressing and receiving, while al-'adl refers to the notion of putting something in its place. Both of these verses emphasize that Islam is a religion of humanity seen from two things. First, an egalitarian attitude can only be born only from a clean heart and a pious heart. As the essence of worship and shari, the righteous are the noblest people who are born not from social status or skin color. Second, the demand to be fair is absolute, both towards people who are favored especially those who are hated. These two messages show that the vision of Islam is rahmatan lil 'ālamīn.

However, to realize the vision of justice above, ethics and procedural steps are needed to show that politics which is loaded with maqāsisid al-sharī'ah is part of worship and has transcendental value. One of these ethics is that politics should be accompanied by a vision of transgression that will help determine the quality of political work. Thus, the political work that he does is laden with worship. To support this first step, realistic and measurable programs are needed when running the political wheel which are accompanied by an attitude of trust. Both of these efforts are intended to realize the vision of an egalitarian politics.

\section{Political Ethics and Reform}

Khalil Bishri's other contribution regarding political ethics is his idea of reforming political parties which have lately found relevance and momentum. Political parties are one of the important pillars of representative democracy in addition to the executive, legislative, judiciary, press freedom, general elections and civil society. Even in the third constitutional amendment in 2001, political parties were placed as the only institution that has the function and responsibility of recording public officials through elections, both legislative and presidential elections. Once the importance of the party's existence, Khalil Bishrī elaborated on the party in a separate article and was supplemented by the idea of party reform in the article on Political Ethics.

Great optimism on the role of political parties is very reasonable because historically, political parties have played an important role in finding and finally "finding" Indonesian identity including the struggle for the foundation of diversity for independent Indonesia. The leaders of the movement, ranging from HOS Cokroaminoto, Soekarno, Hatta, to Sjahrir and M Natsir, not only raised the party, but also made political parties the locomotive of the struggle towards a more just Indonesia. This important and strategic role lasted until the late 1950s before the parties were buried by Sukarno under Guided Democracy (1959-1965) and Suharto for 32 years as the New Order authoritarian regime (1966-1998).

Great optimism on the role of political parties is very reasonable because historically, political parties have played an important role in finding and finally "finding" Indonesian identity including the struggle for the foundation of diversity for independent Indonesia. The leaders of the movement, ranging from HOS Cokroaminoto, Soekarno, Hatta, to Sjahrir and $\mathrm{M}$ Natsir, not only raised the party, but also made political parties the locomotive of the struggle towards a more just Indonesia. This important and strategic role lasted until the late 1950s before the parties were buried by Sukarno under Guided Democracy (1959-1965) and Suharto for 32 years as the New Order authoritarian regime (1966-1998).

But this great optimism is not always directly proportional to the political reality of democracy today. Instead of the fall of the New Order, it became the momentum of the reincarnation of political parties that could bring serious problems, but until two decades after this reform, political 
parties seemed to have never carried out political reform. It is precisely the bad image that appears such as cases of bribery and corruption and the bad behavior of party elites. The Indonesian Institute of Sciences (LIPI) for example, released a survey of Mapping Political, Economic, Socio-Cultural, Defense and Security Conditions ahead of the 2019 Concurrent Election. In the study held in April-July 2018, the researchers found that the People's Representatives and political parties (political parties) get the worst perception as a democratic institution. So that, instead of being a solution, political parties often become part of the obstacles to democracy.

Head of the LIPI Political Research Center Firman Noor saw the House of People's Representatives and political parties not functioning well in the community. The lack of cadre and the poor system in the political parties is called the root of the poor performance of the People's Representatives. Firman considered that political parties now seemed unable to play a role as a means of political education for the public. Political parties actually take an instant path in every election to win.

To avoid further depravity, it became relevant to listen to the idea of political party reform written by Khalil Bishrī, four years before the fall of the New Order era. Of the 14 points of the idea of reforming political parties offered, broadly speaking can be classified as follows:

1) In addition to the vision of piety, political parties must have a clear paradigm and ideology that will facilitate political work. Clarity of paradigm and ideology also serves to anticipate the silting of the political meaning that is suggested to merely seize and maintain power. As a result, ideology is always absent from the essence of the life of political parties or if there is an ideology, nothing more than performance or mere lips service.

2) The need for political parties has a party platform that can accommodate and unite ideas for common goals and interests. This container has a strategic role in creating ethical systems and standards that can be a reference for political parties and their political parties. With institutionalized ethical standards at least minimize the term "flea jumping or jumping fence" which is commonly done by politicians.

3) Political parties must be public aspirations that are sensitive to people's needs. Thus political parties are not trapped in transactional politics or even become the basis of rent-seeking rather than fighting for public policy. To show its contribution, political parties need to be present at all times as a means of political education, not just before the election.

4) Political parties must have economic independence in carrying out party work. A good politician will not make political parties the source of his livelihood, it must instead make it a source of goodness and benefit. Political parties that do not have economic independence or adequate sources of funds will result in a negligent financial governance system of accountability or a transparent accounting system. Even the dependence on the supply of "unclean" funds from cadres in the executive and legislature makes the financial liquidity of some political parties known only to a handful of party financiers centered on the general chairman and or party owner.

5) The necessity for the existence of a chairman and / or leader of a political party who can bring its member cars to one destination. A party leader can be chosen because it has characteristics such as charismatic, good character, acceptable presence, resilience, understanding party problems and being able to solve them.

\section{CONCLUSION}

The idea of Khalil Bishri about political ethics found its relevance when the political dynamics in Indonesia lately showed a shift in political meaning to be reductive. As a politician and sociologist who has a strong religious background, his political ideas are embedded in the framework of benefit as the essence of political goals (maqāșid al-siyāsah). The benefit of this type of politics is the most important spectrum in politics driven by love and humanity. Unlike the benefit of politics, it is banal politics as opposed to civilized politics which in the term khalil bishrī is called al-siyāsah al-limālimah. This banal politics is a type of politics that does not contain the maqāșid al-sharī'ah at all if it is not called destructive politics. Politics that are held only for political interests or merely procedural democracy based on mere political rights are neglected by the values and morality of the nation.

Khalil Bishri also mentions the art of political benefit with the terms al-siyāsah al-'ādilah which is in harmony with the maqāșid al-sharī'ah by making religion a source of ethics. Politics using reference to religious ethics is something that is justified, even obliged and not vice versa using religious clothes for political purposes. In the context of the necessity of power accompanied by ethics, politics is not only the art of managing but it is a noble act because it is based on ethical and moral values. The consequence of this benefit of politics is the realization of the goal of the maqāșid al-sharī'ah, one of which is the birth of an egalitarian policy and political system.

Khalil Bishri's other contributions regarding political ethics are his ideas about reforming political parties which have lately found their relevance. Some of his ideas written four years before the reform era such as the necessity of political parties having a clear direction of the paradigm, must political parties become a forum for public aspirations that are sensitive to people's needs and have a party platform that can accommodate and unite ideas for common goals and interests. The idea of reforming other political parties is the need for political parties to have economic independence in carrying out party work which results in an accountable financial governance system or a transparent accounting system.

\section{REFERENCES}

[1] An-Nabrāwī, Khadījah, 2008, Mausū'ah Ushūl al Fikr as-Siyāsī wa alIjtimā'î wa al-Iqtișādî, Kairo: Dār al Salām.

[2] As-Shalābi, Muḥammad, 2007, Al Wasaṭiyyah fi al Qur'ān al Karīm, Kairo: Dār Ibnu al-Jauzī.

[3] Aziz, Munawir, "KH Bisri Musthofa: Singa Podium Pejuang Kemerdekaan”, NU Online. Diakses pada 22 Agustus 2018.

[4] Bishrī, Muhammad Khalīl, t.t., Al-Durr al-Rambānī, Jawa Tengah: MKW dan DKW PPP

[5] Haris, Syamsuddin, "Keniscayaan Reformasi Parpol” dalam Kompas edisi 14 September 2018. 
[6] Hendropriyono, 2009, Terorisme Fundamentalisme Kristen, Yahudi, Islam, Jakarta: Kompas.

[7] Huda, Akhmad Zainul, 2005, Mutiara dari Pesantren: Perjalanan Khidmah KH. Bisri Musthofa, Yogyakarta: LKIS.

[8] Irfan, Agus, 2018, "Quo Vadis UU Ormas Dalam Dinamika Gerakan Islam Indonesia”, dalam Annual Conference for Muslim Scholars, ed. M. Nuril Huda, et al. Surabaya: Kopertais Wilayah IV.

[9] Khaldūn, Abdul Rahmān Ibn, t.t., Al-Muqadimah, Beirūt: Dār al-Fikr.

[10] Kiras, James D. 2005, "Terrorism and Globalization" dalam John Baylis \& Stave Smith (ed), The Globalizaion of World Politics: An Introduction to International Relations, New York: Oxford University Press

[11] Riyanto, E. Ermada, 2014, Berfilsafat Politik, Yogyakarta: PT Kanisius.

[12] Șafiyyah, Fakhrī Khalīl Abū, 1982, Muhādharāt fí al Siyāsah al Syar 'iyyah, Madīnah: Al Mamlakah al 'Arabiyyah.

[13] Suseno, Franz Magnis, 1986, Kuasa dan Moral, Jakarta: PT Gramedia.

[14] Williams, Paul D. (ed), 2008, Security Studies in Introduction, London: Routletge.

[15] Viotty, Paul R. and Mark V. Kauppi, 2007, International Relations and World Politics: Security, Economy, Identity, New Jersey: Pearson Education Inc.
[16] Winarno, Budi, 2014, Dinamika Isu-Isu Global Kontemporer, Yogyakarta: CAPS.

[17] Qodir, Zuly, "Banalitas Politik Kewargaan" dalam Kompas edisi 6 September 2018.

[18] "Bibit Terorisme di Kampus", Tempo (28 Mei - 3 Juni 2018), 23.

[19] https://nasional.tempo.co/read/1029476/surveiberjihad\#fw4jtXi4Ue3WHXhM.41. Accessed on June 32018.

[20] http://www.nu.or.id/post/read/40566/mengenal-almarhum-kh-cholilbisri. Accessed on Tuesday August 212018.

[21] https://www.gatra.com/rubrik/nasional/partai-politik/336573-SurveiAhli-2018-Kinerja-Parpol-Paling-Buruk. Accessed on October 15 2018.

[22] https://www.cnnindonesia.com/nasional/20180808001644-32320404/survei-lipi-dpr-parpol-jadi-lembaga-bercitra-negatif. Accessed on October 152018.

[23] https://seword.com/umum/mengenal-lebih-dekat-muslim-cyber-mcar1cwbLOdf. Accessed on June 12018.

[24] https://kompas.id/baca/opini/2018/09/12/separasi-agama-negara-danmitos-modernitas/. Accessed on October 142018. 